DOI https://doi.org/10.18551/rjoas.2018-11.18

\title{
COMMUNICATION STRATEGY OF SRIDONORETNO ASSOCIATION IN RED PICK COFFEE PROGRAM
}

\author{
Sugeng Riyanto*, Hardana, Eka Andrean \\ Faculty of Agriculture, University of Brawijaya, Malang, Indonesia \\ *E-mail: suksesbyallah@gmail.com
}

\begin{abstract}
The aim of the research is to describe the sridonoretno association communication strategy in the red picking coffee harvesting program. Qualitative research approach that uses data collection techniques ranging from in-depth interviews (indepth interviews), participatory observation, and documentation. Determination of the sample with simple random sampling technique to the srinoretno association is a combination of 16 farmer groups in the three villages namely Srimulyo, Baturetno, and Sukonodo Village, Dampit District, Malang Regency. Based on the research activities that have been carried out namely for farmers who cultivate coffee participate in training activities that provide education related to the criteria for quality coffee in the red picking program. In addition, farmers follow the practice of harvesting coffee about how to harvest coffee according to the procedure.
\end{abstract}

\section{KEY WORDS}

Red cherry coffee, empowerment, communication, strategy.

Dampit is known as the number one coffee producer in East Java but the amount of coffee production each year shows a declining trend. This decline was caused by the declining coffee prices. Malang is also a district that has the highest production potential in the province of East Java, which is 7,703 tons annually(BPS Jatim, 2014). Although coffee has the highest production rate in the Dampit region, it has not been able to provide welfare to farmers living in the area. This is because farmers do not get a decent price so farmers switch to other commodities. In 2006 coffee production continued to rise from 9255 tons and at its peak in 2010 with a total production of 10028 tons. There was a very drastic decline in 2011, because of the drop in coffee prices at that time, from being able to sell IDR. 20,000 per $\mathrm{kg}$, it was only valued at IDR. 13-14 thousand per kg or slumping to IDR. 7,000 per kg so that it was not comparable to operational costs.

The imbalance of production costs with coffee yields can be overcome by finding new markets at better prices. The target of the new market in question is the market for "Premium" coffee or good quality coffee so that it can provide a bargain price of coffee that is higher than the usual market price. The market automatically only receives good quality coffee so it demands coffee farmers to increase their coffee production. Coffee quality improvement cannot be achieved in just one process stage, but can only be achieved by improving a series of efficient processes from processing coffee from the garden, harvesting patterns, and post-harvest coffee. And this improvement must be carried out consistently so that the market is confident of the quality of the coffee produced by farmers. To produce coffee with good quality, a number of programs are needed, one of which is the red picking program in order to improve the quality of coffee on the post-harvest side. The red picking program is required by a strategy in inviting quotes to make improvements to the penennya pattern. Strategies related to how to treat the program to farmers.

\section{METHODS OF RESEARCH}

This study uses a qualitative approach, namely the process of extracting data to understand social phenomena based on holistic research, shaped by words, and obtained from natural situations. Determination of the sample with simple random sampling technique to the srinoretno association is a combination of 16 farmer groups in the three villages 
namely Srimulyo, Baturetno, and Sukonodo Village, Dampit District, Malang Regency.In applying this qualitative approach, it is used to understand the phenomena of the dynamics of social capital in marketing vegetables in Tawangargo Village

\section{RESULTS AND DISCUSSION}

Strategy for Conducting Red Picking Program Socialization. At present the group has carried out the red picking process for some of its members and coffee is still processed with technology that is almost the same as belusrandart harvesting technology where it is still dried like dried coffee is needed improvements in the processing sub-section. At present there is no co-formation yet, so marketing is still managed by the association and assisted by partners who buy coffee, which is the parade wall shop and the Malang store association.

The targets that will be achieved for the 2016 pre-period are pre-copracy mature and ready to be used as a copration. Ready in terms of organization and also ready in terms of management. Then the target related to the coffee produced from the management of coprasi is the achievement of coffee results on the medium standard to be marketed in the market. Activities carried out by the Association to support and succeed in the red boarding activities are as follows

Conduct trainings. Post-penen training basically has 2 main points, the first is the red picking harvesting process and the second is the correct processing, starting from pulper, drying, slipping into greenbean, and slaughtering. At the stage of the 2015 harvest season we have done the socialization of the red picking press with $95 \%$ red and $5 \%$ red yellow, while the green and black ones should not be available. Then at the harvest stage in 2016 the process of understanding red picking was repeated again at the level of the group leader, why only the group leader, with consideration that you were repeated to the members was very ineffective, and when told to the group leader would be more effective because the group leader would be the quality controller which will control each member who will red pick.

At the kelopok chair level, understanding and learning related to the process of collecting coffee correctly with various processes as follows

1. The first natural process;

2. Honey process;

3. Wet Process.

Understanding the process is intended so that the group leaders of all groups, especially the groups to be established by UPH, will understand and become leaders in the process to be carried out at UPH. Why do not the members make a revision, because the strategy used is an understanding of the members when the members deposit red coffee at UPH. Members will learn directly the process desired by the market. In addition to speeding up the separation, there were also distributions of videos that showed the correct process of collecting coffee. These videos were disseminated through existing group chairmen.

Red picking and processing practices. Market demand is very urgent so it was decided to provide an understanding of the sridonoretno association management. Knowledge of the quality of red pickings is owned by the management since a long time ago. And when this program runs we only re-emphasize the understanding that they have had through a discussion and also the practice in the garden about what red pick knowledge is like. An example of that knowledge is; 1 . Coffee must be cerry red-colored, 2 . There should not be black or even dry, 3. Yellow color is a maximum of $5 \% 4$. There should be no green 6 . Coffee must be fress and should not be stored more than 24 hours, 7 . storage may not be in a sack but let it be touched. We deepen that knowledge through discussion and also get input and direction and PTNN 12 farm gardens.

Make processing units in each group. Here it hasn't arrived at what is called processing, but it's still just a collection and control of red quotes. Where each group is given the obligation to collect red coffee from each member to be sold to partner companies. In the future, we hope that each group will have its own processing unit. To realize that dream, the group always has a dialogue with related agencies to get the help of processing equipment. 
Make a feasibility study. The feasibility study made for this joint marketing activity is still very simple where a feasibility study is used to compare the profits obtained from farmers when conducting a selling partnership in red compared to selling dry rice.

\section{CONCLUSION}

Based on the results of research and data analysis that has been done, the following conclusions are obtained. In conducting program extension to the community, it requires a number of strategies to enable the community to conduct a red picking program to improve the quality of the coffee harvest. The first one is done by training that educates farmers about the quality of coffee. The second is the practice of red ptik to provide farmers with skills that are good for coffee. The three production processing units are formed in each group to facilitate members to access the red picking program while providing continuous education. Finally, no less important is the business analysis activity, meaning that it is comparing whether the quality of the coffee is better than the management of coffee with carelessness.

\section{REFERENCES}

1. Adena, Rikyanto; Najib, Husain; Harnina, Ridwan. (2012). Communication Strategy of the Southeast Sulawesi Provincial Forestry Service in Relocating Communities Around the Tahura Nipa-Nipa Forest Area in Kendari City.

2. B. N. Rasila and M. J. Mudau.(2012). Effective communication as a strategic tool for rural development: A model to take South African Government beyond mobilization and consultation through public participation. Journal of Media and Communication Studies Vol. 4(7), pp. 134-141.

3. Burger, K. Kameo, D. \& Sandee, H. (2001). Clustering of Small Agro-Processing Firms in Indonesia. International Food and Agribusiness Management Review, 2(3/4): 289-299.

4. Cangara Hafied. (2013). Communication Planning and Strategy. Jakarta: Rajawali Pers.

5. Caporale, G. M. \& Sova, R. (2015). Trade Flows And Trade Specialisation: The Case Of China. Working Paper No. 15-07.

6. Churmen, Imam .(2001). Save sugar industry in Indonesia. Millenium Publisher. Jakarta.

7. Delroy Anthony Armstrong.(2004). The Potential Impact of Trade Policychanges On Caribbean Sugar. B.S., Louisiana State University.

8. Effendy, O U. (1990). Communication Studies. Theory and Practice. Bandung: PT Remaja Rosdakarya.

9. Creswell, John W. (2013). Research Design: Qualitative, Quantitative, and Mixed Third Edition approaches. Yogyakarta: Pustaka Pelajar.

10. Haroon Sseguya, Robert Mazur\$, Eric Abbott\$\$ And Frank Matsiko.(2012). Information and Communication for Rural Innovation and Development: Context, Quality and Priorities in Southeast Uganda. Journal of Agricultural Education and Extension. Vol. 18, No. 1, 5570.

11. Haley, Stephen.2013. World Raw Sugar Prices The Influence of Brazilian Costs of Production and World Surplus/ Deficit Measures. United States Department of Agriculture

12. Indriyanto. (2010). Forest Ecology. Jakarta: PT Bumi Aksara.

13. Matsumura, Kanichiro.(2010). Demand and Supply Structure for Food in Asia. Sustainability 2011, 3, 363-395; doi:10.3390/su3020363.

14. McConnell, Michael; Erik Dohlman; Stephen Haley. (2010). World Sugar Price Volatility Intensified by Market and Policy Factors.

15. McCormick, A. J. Watt, D. A. and Cramer, M. D.(2009). Supply and demand: sink regulation of sugar accumulation in sugarcane. Journal of Experimental Botany, Vol. 60, No. 2, pp. 357-364.

16. Mulyana, Deddy. (2001). An Introduction to Communication Studies. Penerbit PT Remaja Rosdakarya. Bandung.

17. Peter Walton, Dr Gashaw Kebede.(2012). Information and Communication Management Strategy Development. 
18. Ricardo Ramírez and Wendy Quarry (2004). Communication Strategies In The Age Of Decentralisation And Privatisation Of Rural Services: Lessons From Two African Experiences. Agricultural Research \& Extension Network.

19. Rumánková, Lenka and Smutka, Luboš. (2013). Global Sugar Market - The Analysis Of Factors Influencing Supply and Demand. Volume LXI. No. 2, pp. 463-471.

20. Sa'diyah, C. (2014). Factors that influence of economic performance for crystal sugar in Indonesia. (Thesis). Faculty of Agriculture. University of Brawijaya. Malang.

21. Sinaga, N. (2006). Model Econometric Aplication. IPB Post Graduate. Bogor.

22. Sugiyono, (2014). Mixed Methods, Bandung: Alfabeta.

23. Susila, Wayan.R dan Bonar M. Sinaga. (2005). Analysis of Sugar Industry Policy in Indonesia. Jurnal Agro - Ekonomi Volume 23 No. 1, page 30-53.

24. Xue Xu and Hailong Xia.(2014). Analysis and Outlook of China's Sugar Industry Development. Proceedings of Selected Articles of 2013 World Agricultural Outlook. 